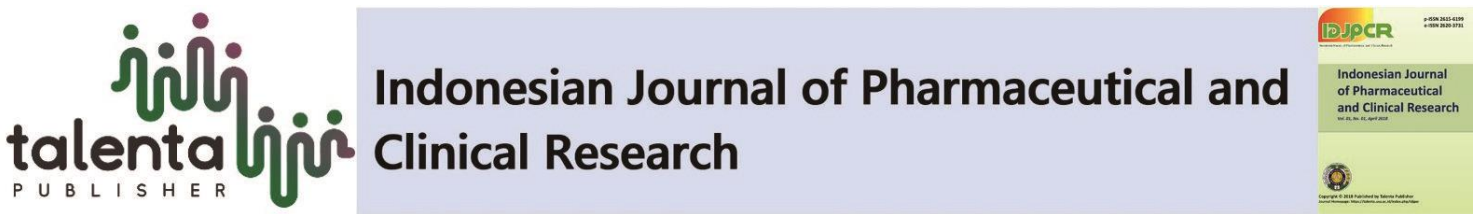

\section{Mineral Analysis in Dioscorea hispida Dennst. Tuber by Atomic Absorption Spectrophotometry}

\author{
Masfria*, Rehulina Gultom, Tedy Prayoga. \\ Department of Pharmaceutical Chemistry, Faculty of Pharmacy, Universitas Sumatera Utara, \\ Medan 20155, Indonesia
}

\begin{abstract}
The purpose of this study was to analyze minerals in gadung (Dioscorea hispida Dennst.) tuber. The analysis of minerals was conducted by using atomic absorption spectrophotometry. The results showed that the concentration of iron, cadmium, potassium, calcium, sodium, magnesium, copper and zinc were $0.6445 \pm 0.0029 \mathrm{mg} / 100 \mathrm{~g}, 0.0011 \pm$ $0.0083 \mathrm{mg} / 100 \mathrm{~g}, 265.2780 \pm 0.4652 \mathrm{mg} / 100 \mathrm{~g}, 5.1015 \pm 0.0490 \mathrm{mg} / 100 \mathrm{~g}, 8.3011 \pm 0.0974$ $\mathrm{mg} / 100 \mathrm{~g}, 29.0237 \pm 0.0706 \mathrm{mg} / 100 \mathrm{~g}, 0.1110 \pm 0.0019 \mathrm{mg} / 100 \mathrm{~g}$, and $0.6113 \pm 0.0026$ $\mathrm{mg} / 100 \mathrm{~g}$, respectively.it can be concluded that The gadung (Dioscorea hispida Dennst.) tuber contains iron, cadmium, potassium, calcium, sodium, magnesium, copper and zinc as the minerals.
\end{abstract}

Keywords: Gadung tuber, Dioscorea hispida Dennst., atomic absorption spectrophotometry.

\begin{abstract}
Abstrak. Tujuan dari penelitian ini adalah untuk menganalisis mineral yang terdapat pada umbi gadung (Dioscorea hispida Dennst.). Analisis mineral dilakukan dengan menggunakan spektrofotometri serapan atom. Hasil penelitian menunjukkan bahwa konsentrasi besi, kadmium, kalium, kalsium, natrium, magnesium, tembaga dan seng adalah 0,6445 + 0,0029 $\mathrm{mg} / 100 \mathrm{~g}, 0,0011+0,0083 \mathrm{mg} / 100 \mathrm{~g}, 265,2780+0,4652 \mathrm{mg} / 100 \mathrm{~g}, 5,1015+0,0490 \mathrm{mg} /$ $100 \mathrm{~g}, 8,3011+0,0974 \mathrm{mg} / 100 \mathrm{~g}, 29,0237+0,0706 \mathrm{mg} / 100 \mathrm{~g}, 0,1110+0,0019 \mathrm{mg} / 100 \mathrm{~g}$, dan 0,6113 + 0,0026 mg/100g, masing-masing. Kesimpulan penelitian ini adalah umbi gadung (Dioscorea hispida Dennst.) memiliki kandungan mineral zat besi, kadmium, kalium, kalsium, natrium, magnesium, tembaga dan seng
\end{abstract}

Kata kunci: Umbi Gadung, Dioscorea hispida Dennst., Spektrofotometri serapan atom Received 28 February 2019 | Revised 07 May 2019| Accepted 27 May 2019

\section{Introduction}

Gadung (Dioscorea hispida Dennst.) tuber is one type of tubers that grows wild in forests, yards and plantations. Gadung bulbs contain bioactive compounds such as water soluble polysaccharides, dioscorin and diosgenin [1]. Gadung tuber is used by the community to treat leprosy, ulcers, diabetes, heat reduction, anti-rheumatic, phlegm thinners, eliminating menstrual pain, and animal poisons, while the sap is used to treat snake bites and the remaining flour

\footnotetext{
*Corresponding author at: Department of Pharmaceutical Chemistry, Faculty of Pharmacy, Universitas Sumatera Utara, Medan 20155, Indonesia

E-mail address: masfria@usu.ac.id
} 

Gadung (Dioscorea hispida Dennst.) tuber in Deli Serdang Regency, North Sumatra was empirically used to make the body fresher. It is also used as food such as chips and for cancer treatment. Minerals are part of the body that plays an important role in maintaining body functions at the cellular level, tissues, organs and the body functions as a whole. Minerals also play a role in various stages of metabolism, especially as a co-factor of enzymes. The balance of enzymes, maintenance of acid-base balance, helps transfer important bonds through the cell membrane and maintains the sensitivity of muscles and nerves to stimuli were several of the minerals functions [3]. Minerals are classified into macro and micro minerals. Macro minerals are minerals that the body needs in amounts of more than $100 \mathrm{mg}$ per day, while micro minerals are needed less than $100 \mathrm{mg}$ per day [4]. Not all elements absorbed by plants are nutrients. Plant composition is influenced by the soil, environmental conditions, and genetic factors. The composition of plants changes according to the age and plant parts [5]. This study used atomic absorption spectrophotometry method which is based on the accuracy of the instrument, the speed of analysis, does not require preliminary separation and very appropriate to determine the mineral content [6].

\section{Materials And Methods}

\subsection{Plant and chemicals materials}

The instruments used in this study were Atomic Absorption Spectrophotometer (Hitachi Zeeman2000 ) with air-acetylene gas completed with cathode lamps of $\mathrm{Fe}, \mathrm{Cd}, \mathrm{K}, \mathrm{Ca}, \mathrm{Na}, \mathrm{Mg}, \mathrm{Cu}$ and $\mathrm{Zn}$; analytical balance (BOECO), and furnace (Stuart). The materials used in the study were gadung tubers taken from Dusun 2, Bandar Dolok Village, Pagar Merbau Subdistrict, Deli Serdang District, North Sumatera; 65\% nitric acid, and standard solutions for each mineral.

\subsection{Dry Destruction Process}

Sample that had been blended with blender was weighed $25 \mathrm{~g}$ and placed in a porcelain crucible, then it was placed on hot plate and transferred to furnace with initial temperature of $100^{\circ} \mathrm{C}$ and slowly increased to $500^{\circ} \mathrm{C}$ with interval $25^{\circ} \mathrm{C}$ every 5 minutes. The ignition was done until it gave white residue and the ash was left to cool. The ash was moistened with $5 \mathrm{ml}$ of $65 \% \mathrm{HNO}_{3}(1: 1)$, then it was evaporated on the hot plate to dry. Porcelain crucible was put back into the furnace and blanched for 1 hour at $500^{\circ} \mathrm{C}$, then cooled [7].

\subsection{Preparation of Sample Solution}

The cooled ash was dissolved with $5 \mathrm{ml}$ of $65 \% \mathrm{HNO}_{3}(1: 1)$ and then transferred into a $100 \mathrm{ml}$ volumetric flask and the crucible was rinsed 3 times with $10 \mathrm{ml}$ of demineralized water. The result of rinsing was put into a volumetric flask, and then the demineralized water was added sufficiently 
until it reached the mark line. The solution was filtered with Whattman filter paper number 42 . The first filtrate was removed around $5 \mathrm{ml}$ to saturate the filter paper and then the filtrate was collected in a bottle. This filtrate was used as a sample solution for quantitative analysis.

\subsection{Quantitative Analysis}

The preparation of calibration curve for each mineral used the standard solution with several concentrations.The regression equation was calculated and was used to calculate the mineral content in the gadung tubers sample with different dilutions for each mineral. Analysis of iron, cadmium, potassium, calcium, sodium, magnesium, copper and zinc content were measured using atomic absorption spectrophotometry at successive wavelengths of $248.3 \mathrm{~nm}, 228.8 \mathrm{~nm}, 766.5$ $\mathrm{nm}, 422.7 \mathrm{~nm}, 589.0 \mathrm{~nm}, 285.2 \mathrm{~nm}, 324.8 \mathrm{~nm}$, and $213.9 \mathrm{~nm}$, respectively with air-acetylene gas. The data obtained were tested statistically using student $\mathrm{T}$, with $\mathrm{t}$ calculated $<\mathrm{t}$ table, at $95 \%$ confidence interval with a value of $\alpha=0.05$.

\section{Results and Discussion}

Measurement of mineral content in gadung (Dioscorea hispida Dennst.) tubers using atomic absorption spectrophotometer showed good results, where the regression equation correlation coefficients for eight measured minerals showed values close to 1. According to Harmita (2004) as a parameter of the linear relationship was used $r$ in linear regression analysis $Y=a+b X$. The ideal linear relationship is achieved if the value $b=0$ and $r=+1$ or -1 depends on the direction of the line, while the value of a indicates the sensitivity of analysis, especially the instruments used. The results of the determination of linear regression equations of iron, cadmium, potassium, calcium, sodium, magnesium, copper and zinc can be seen in Table 1 and the calibration curve image can be seen in Figure 1.

Table 1. Linear regression equation of iron, cadmium, potassium, calcium, sodium, magnesium, copper and zinc

\begin{tabular}{clcc}
\hline Mineral & \multicolumn{1}{c}{ Regression Equations } & $\begin{array}{c}\text { Correlation } \\
\text { Coefficients }\end{array}$ & $\begin{array}{c}\text { Detection } \\
\text { Limits }(\mu \mathrm{g} / \mathrm{ml})\end{array}$ \\
\hline Iron & $\mathrm{Y}=0.0283542857 \mathrm{X}-0.0002428571$ & 0.9999 & 0.0527 \\
Cadmium & $\mathrm{Y}=0.000136535 \mathrm{X}-0.000188908$ & 0.9996 & 0.000002 \\
Potassium & $\mathrm{Y}=0.08181429 \mathrm{X}+0.00969524$ & 0.9995 & 0.4071 \\
Calcium & $\mathrm{Y}=0.05614286 \mathrm{X}+0.00052857$ & 0.9995 & 0.0374 \\
Sodium & $\mathrm{Y}=0.0389143 \mathrm{X}+0.00014286$ & 0.9997 & 0.0308 \\
Magnesium & $\mathrm{Y}=0.6807285714 \mathrm{X}+0.0072357143$ & 0.9997 & 0.0660 \\
Copper & $\mathrm{Y}=0.0283142857 \mathrm{X}+0.0001380953$ & 0.9997 & 0.0160 \\
Zinc & $\mathrm{Y}=0.3149142857 \mathrm{X}-0.0008812857$ & 0.9995 & 0.0101 \\
\hline
\end{tabular}



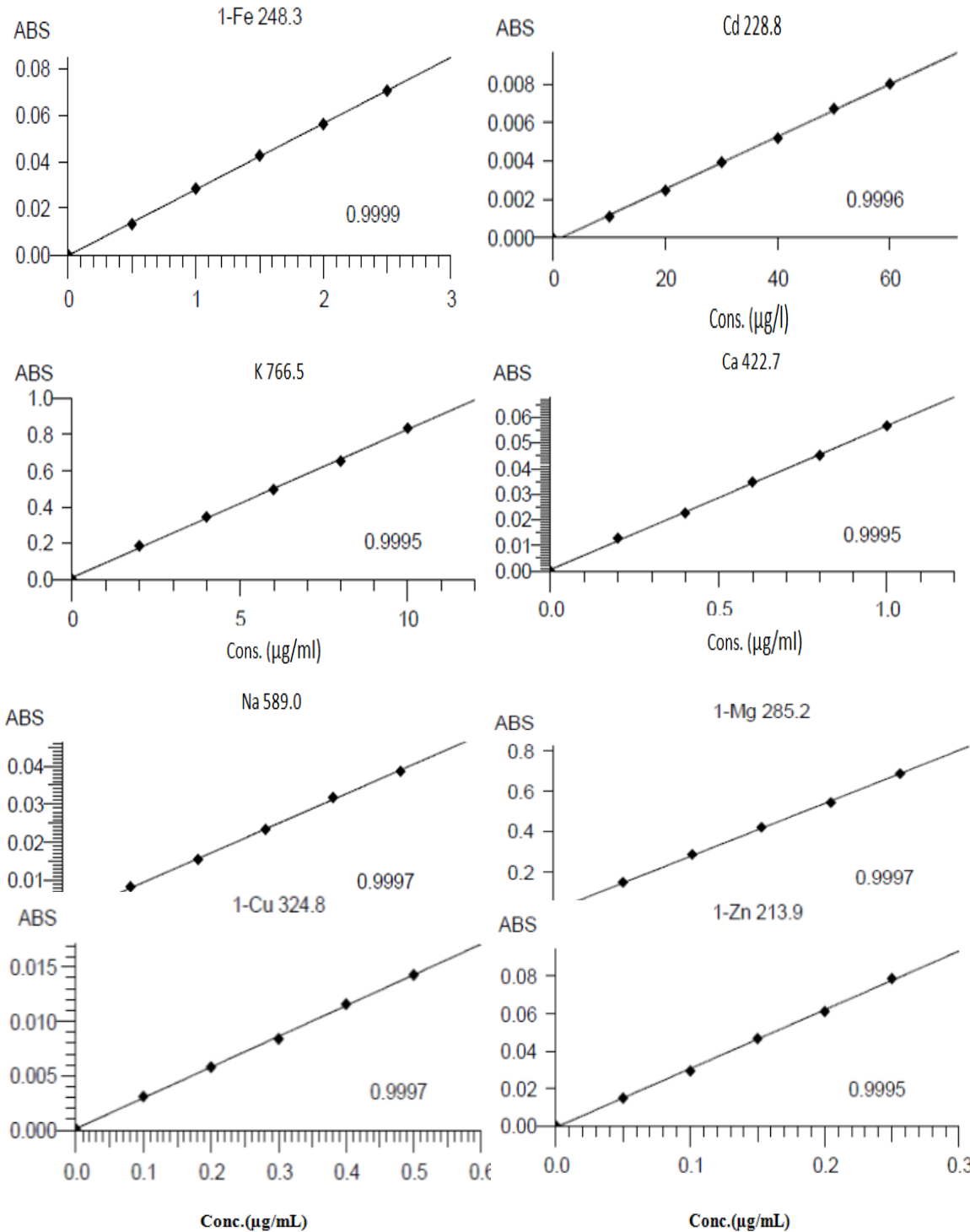

Figure 1.Calibration curve of iron, cadmium, potassium, calcium, sodium, magnesium, copper and zinc minerals

Data obtained from the six repetitions were tested statistically using student $\mathrm{T}$, with $\mathrm{t}$ count $<\mathrm{t}$ table. The concentration of iron, cadmium, potassium, calcium, sodium, magnesium, copper and zinc of gadung (Dioscorea hispida Dennst.) tuber at 95\% confidence intervals with $\alpha$ value $=0.05$ can be seen in Table 2 . 
Table 2. The minerals content of gadung (Dioscorea hispida Dennst.) tuber

\begin{tabular}{lc}
\hline Mineral & Concentration $(\mathbf{m g} / \mathbf{1 0 0 g})$ \\
\hline Iron & $0.6445 \pm 0.0029$ \\
Cadmium & $0.0011 \pm 0.0083$ \\
Potassium & $265.2780 \pm 0.4652$ \\
Calcium & $5.1015 \pm 0.0490$ \\
Sodium & $8.3011 \pm 0.0974$ \\
Magnesium & $29.0237 \pm 0.0706$ \\
Copper & $0.1110 \pm 0.0019$ \\
Zinc & $0.6113 \pm 0.0026$ \\
\hline
\end{tabular}

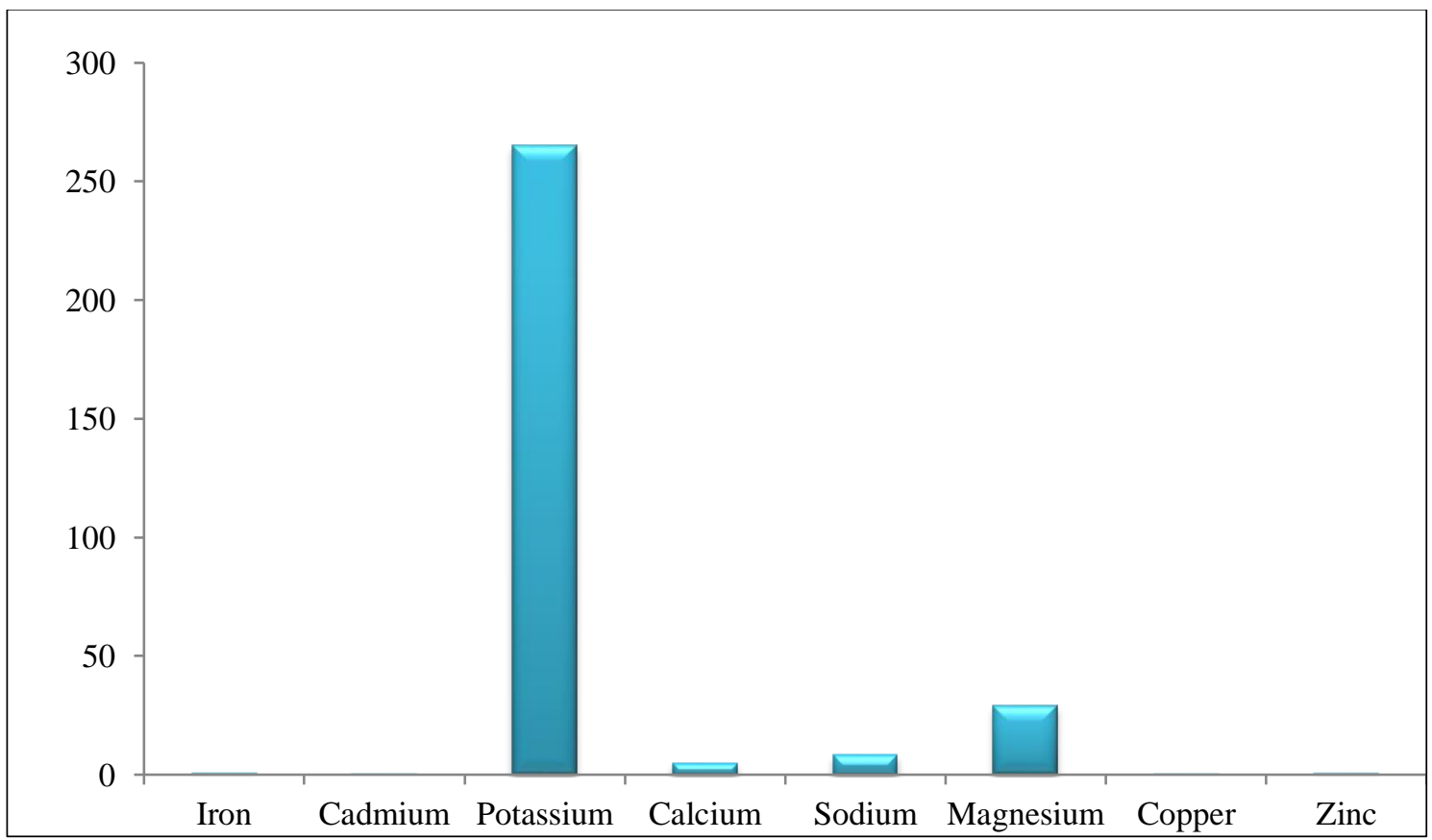

Figure 2: Mineral content of gadung (Dioscorea hispida Dennst.) tuber

Minerals are generally insensitive to heat, but are susceptible to washing or processing involving water such as boiling. Water soluble food during boiling will decrease its nutritional value especially water soluble vitamins and minerals[8]. Plant composition is influenced by soil, environmental conditions, and genetic factors. The composition of plants changes according to age and plant parts. The cation content of the plant is constant or in other words the elements can replace each other [5]. 


\section{Conclusion}

Gadung tuber minerals consist of iron, cadmium, potassium, calcium, sodium, magnesium, copper and zinc with concentration of $0.6445 \pm 0.0029 \mathrm{mg} / 100 \mathrm{~g}, 0.0011 \pm 0.0083 \mathrm{mg} / 100 \mathrm{~g}$, $265.2780 \pm 0.4652 \mathrm{mg} / 100 \mathrm{~g}, 5.1015 \pm 0.0490 \mathrm{mg} / 100 \mathrm{~g}, 8.3011 \pm 0.0974) \mathrm{mg} / 100 \mathrm{~g}, 29.0237 \pm$ $0.0706 \mathrm{mg} / 100 \mathrm{~g}, 0.1110 \pm 0.0019 \mathrm{mg} / 100 \mathrm{~g}$, and $0.6113 \pm 0.0026 \mathrm{mg} / 100 \mathrm{~g}$, respectively.

\section{Acknowledgement}

The authors are gratefully thank to Faculty of Pharmacy University of Sumatera Utara for providing the technical facilities.

\section{REFERENCES}

[1] R. Sumunar, and T. Estiasih, T, "Gadung (Dioscorea hispida Dennst.) tuber as food source containing boactive compound", Jurnal Pangan and Agroindustri, vol 3 no. 1, pp. 108110.2015 .

[2] S. R. Santi, "Active compound of Gadung (Dioscorea hispida Dennst.) tuber as anorexia compound". Jurnal Kimia. vol. 4, no.1, pp. 71-78. 2010.

[3] E.E. Sibagariang, Nutrients in Reproductive Health, First edition. Jakarta: Trans Info Media, pp. 58-59.2010.

[4] S. Almatsier, S. Basic Principle of Nutrients. Jakarta: PT. Gramedia Pustaka Utama. 2014

[5] K.A. Hanafiah, The basic of Soil Science. Sixth Edition, Jakarta: Rajawali Pers. Pp. 254. 2005

[6] S.M. Khopkar. Basic Concepts of Analytical Chemistry. First Edition. New York: New Age Science.1985.

[7] K. Helrich, Official Methods of Analysis. Fifteenth Edition. Virginia.: Association of Official Analytical Chemists, Inc.1990

[8] E.S Rahayu,and P. Pribadi, "Concentration of Vitamin and Minerals in Fruit fresh candied of Carica pubescenes Lenne \& K. Koch" Biosantifika Berkala Ilmiah Biologi, vol.4, no.2, pp. $90-93.2012$ 